\title{
When poverty knocks on the door: Sharing the story of low income single mothers in Kelantan
}

\author{
Zarina Md Nor ,Nur Zhafirah Mohamad”,Suresh Kumar N Vellymalay\$ \\ "School of Distance Education, Universiti Sains Malaysia \\ \#Bahiyah Omar School of Communication, Universiti Sains Malaysia \\ ${ }^{\$}$ Azizah Omar School of Management, Universiti Sains Malaysia
}

(Received 14 September 2018, accepted 02 May 2019)

https://doi.org/10.36224/ijes.120203

\begin{abstract}
Single mother households are often associated with financial hardships as they have lost financial support from the spouse upon divorce. This preliminary study presents the story of hardships among 12 selected single mothers with children in Kelantan. A survey questions has been distributed and the descriptive data has been collected and analyzed with their consent. We find that demographic and socio-economic factors play important roles in the financial wellbeing of the respondents whereby the low education attainment seems to cause the respondents to have low paying jobs exacerbated by more than average number of children in the households and an absence or irregularity of child support payments from their former husband. Hence, the findings further highlight the additional burden faced by the single mothers due to unavailability child support payment for various reasons. It is important to note that the income of all of our respondents fall under the minimum wage of the country therefore they are considered poor and very poor from per capita point of view. Poverty and hardships come hand in hand therefore public assistance in the form of cash and housing arrangements have somehow reduced the burden of single mothers in this study. Consequently, we believe that this brief study has invoke more questions that warrant further studies on many topics involving single mother households such as child support, child poverty and financial and economic wellbeing of single mothers households in Malaysia. So where do we start?
\end{abstract}

Keywords: single mother, poverty, child support, public assistance, Kelantan

\section{Introduction}

Poverty alleviation has been given an appropriate attention by the government since long ago. The effort has managed to greatly reduce the level of poverty in the society yet there are pockets of people who remain poor due to their life's condition. Poverty can be classified into five categories, namely financial poverty which includes employment, income and liabilities; poverty status related to housing, physical environment, health and nutrition; poverty participation that includes transport systems and structural factors; capacity poverty involving knowledge and skills; and spiritual poverty that reflects morality and morals, religious beliefs, globalization and economic competition [2]. The topic of poverty relates to some of the keywords such as insufficiencies, shortcomings and hardships faced by individuals, families, and communities whereby the monthly household income and the number of dependents have been extensively used for measurement of poverty [1]. Poverty and single motherhood have often been associated in the literature as the incident of poverty among female headed households is generally higher than the general population. In this study we briefly examine the poverty issue among selected single mothers in Kelantan.

The 2016 Household and Basic Income Survey Report for Malaysia stated that the incidence of poverty is at $0.4 \%$ of the total population affecting 6.9 million households with the average household size of 4.1 people [3]. The report also details that the median income of RM5, 228 while the average income is RM6, 958 that come from four main 
sources of income namely paid employment, self-employment, asset/investment and transfers. The Federal Territory of Kuala Lumpur recorded the highest median income at RM9, 073 while Kelantan recorded the lowest median income of RM3, 079. This statistic shows that Kelantan is the poorest state in Malaysia, somehow supporting the location of this study.

In 2015, the Ministry of Women, Family and Community Development pursuant to the Single Mothers Action Plan has redefined a single mother as a divorced or widowed female household head with unmarried children living together; a female household head with a sick or unemployed husband and having unmarried children in the household; or a female unmarried household head with adopted or out of wedlock children [21]. Following the redefinition, the number of single mothers (widow, divorcee and permanently separated women) the Population and Housing Census Report 2010 reported has decreased to 235,000 from the initial figure of 831,860 . Thus single mother represents an approximately 1.7 per cent of the total population in 2010 but the increasing trend is noted as there were only 104,991 single mothers were recorded in the report for the year 2000 [4]. However, there are only 83,775 single mothers registered with the Department of Women's Development recently [4]. Hence, it raises a question on the whereabouts of the rest of the single mothers such that programs and activities run by the department may not reach those who need it the most. The reason behind such a low registered numbers should be found as well though it is beyond the scope of this study.

\section{Literature review}

Poverty has become an economic, social, and political issue all over the world particularly in developing and third-world nations [5]. In an economic point of view, poverty is defined as a situation that shows disability from minimum income which is needed to fulfil necessities of food, clothes, shelter and basic infrastructure [6]. This fascination with income is driven by humanitarian impulses, the desire for improvements in the quality of life [7]. The of poverty eradication programs involve many factors such as socio economic and economic factors to really have significant impact on reduction of poverty [8]. As stated in the 11th Malaysia Plan (RMK-11), the government emphasises on economic growth to improve socio-economic development of the nation. Poverty in Malaysia has been conceptualised as economic or income poverty and is being measured using a Poverty Line Income (PLI) to differentiate the poor and the non-poor households [9]. A household is considered poor if its income is less than its Poverty Line Income (PLI) meaning that it lacks the resources to meet the basic food and non-food needs of its individual members. In general, life becomes difficult when income is low thus negatively affecting the general wellbeing and life satisfaction [10]. In addition, single mothers have to face emotional and psychological issue as well as social stigma in the community [21].

Marital status indicates differences in life satisfaction whereby single women, divorcees or widows are reported to have lower life satisfaction than married women [11]. The socio-economic factors such as education, employment, income and family size seem to have profound impact on the tendency to be poor whereby the unemployed single mothers with low education attainment and multiple children are more likely to be poor [12] in other words, family size may contribute to the incidence of poverty [15]. Further, the percentage of children living in poverty rises considerably for families with three or more children [16] as the expenditure increases accordingly [17]. This is where the role of child support from absent fathers becomes crucial in ensuring the wellbeing of the children post-divorce/separation. However, child support remains a delicate issue on the 
personal as well as on the policy level as it involves balancing the complex and competing needs of children, resident parents, non-resident parents and the government [18]. Undeniably, the payment of child support becomes an important source of income for single mothers to make up for the financial shortfall post-divorce/separation [19].

In many cases, the single mothers have to shoulder most of the responsibilities of caring for the children that may cause them to stress out and affect their life satisfaction in particular when they earn a little [6]. In addition, single mothers are more likely to be employed in low paid job which is probably due to their education level [13]. Basically, education is a gateway to job opportunity and sufficient income and the lack of it may deteriorate household economic situation [16]. It is also shown that the education background of the head of the family may also affect the education achievement of the children in the household [15]. Moreover, the education level and employment status further affect entrepreneurial orientation which has the ability to assist the households in their endeavour to obtain extra income and to get out of poverty [14]. Further, the place of residence is found to affect opportunities in education, employment and income whereby more opportunities exist in urban areas compared to rural areas [15].

\section{Methodology}

In this study, we use a survey form to collect the demographic and descriptive information of the respondents. This technique is sufficient to provide necessary information needed to fulfil the objectives of this study. A total of 12 Malay single mothers are selected to be included in this study. All of the respondents have stated their consent to be a part of this research. All of the respondents live in Kelantan and those selected are less than 50 years of age. The data and information obtained from the survey forms are analysed and presented accordingly.

\section{Results and discussion}

A total of 12 selected single mothers have participated in this study. Table 1 shows the descriptive statistics of the respondents. Most of the respondents $(58.33 \%)$ aged between 42 to 47 years old while the rest aged between 24 to 41 years old. More than half of the respondents have become single mothers for 6 years and below while 2 respondents have been living as a single mother for between 11 and 12 years. For education level, it is obvious that most of them have low educational attainment (lower secondary school and primary school levels) which later affects the kinds of employment that they involved in (low paid jobs) and the monthly income that they earned (RM1000 and below). The results show that the respondents' earnings are equal or below the Minimum Wage Order 2016 P.U (A) 116 of RM1000 per month, gazetted on April 29, 2016 and effective from 1 July 2016 to 31 December 2018. Hence, the lower educational attainment may exacerbate the incidence of poverty [6] and may lead to intergenerational poverty whereby poverty is inherited from parents to children [22]. Also, the children from low-income families are in disadvantage in their pursuit of education due to inadequate finances [26]. 
Table 1: Descriptive statistics

\begin{tabular}{|c|c|c|c|}
\hline & & $\mathrm{n}$ & $\%$ \\
\hline \multirow[t]{4}{*}{ Age (years) } & $24-29$ & 2 & 16.66 \\
\hline & $30-35$ & 1 & 8.33 \\
\hline & $36-41$ & 2 & 16.66 \\
\hline & $42-47$ & 7 & 58.33 \\
\hline $\begin{array}{l}\text { Duration of being a } \\
\text { single }\end{array}$ & $1-3$ & 4 & 33.33 \\
\hline \multirow[t]{3}{*}{ mother (in years) } & $4-6$ & 4 & 33.33 \\
\hline & $7-9$ & 2 & 16.66 \\
\hline & $10-12$ & 2 & 16.66 \\
\hline \multirow[t]{4}{*}{ Education level } & Primary school & 2 & 16.66 \\
\hline & Lower Secondary school & 7 & 58.33 \\
\hline & Upper Secondary school & 2 & 16.66 \\
\hline & Tertiary education & 1 & 8.33 \\
\hline \multirow[t]{7}{*}{ Employment } & Janitor & 4 & 33.33 \\
\hline & Religious teacher & 1 & 8.33 \\
\hline & Salesperson & 1 & 8.33 \\
\hline & Factory worker & 1 & 8.33 \\
\hline & Child carer & 1 & 8.33 \\
\hline & Masseuse & 1 & 8.33 \\
\hline & Not working & 3 & 25.00 \\
\hline \multirow[t]{6}{*}{ Monthly income } & RM501 - RM600 & 1 & 8.33 \\
\hline & RM601 - RM700 & 2 & 16.66 \\
\hline & RM701 - RM800 & 1 & 8.33 \\
\hline & RM801 - RM900 & 4 & 33.33 \\
\hline & RM901 - RM1000 & 1 & 8.33 \\
\hline & No paid income & 3 & 25.00 \\
\hline \multirow[t]{5}{*}{ Financial Aid (monthly) } & RM100 and below & 1 & 8.33 \\
\hline & RM101 - RM200 & 4 & 33.33 \\
\hline & RM201 - RM300 & 4 & 33.33 \\
\hline & RM301 - RM400 & 1 & 8.33 \\
\hline & Not a recipient & 2 & 16.66 \\
\hline \multirow[t]{4}{*}{ No. of children } & $1-2$ & 2 & 16.66 \\
\hline & $3-4$ & 6 & 50.00 \\
\hline & $5-6$ & 2 & 16.66 \\
\hline & $7-8$ & 2 & 16.66 \\
\hline \multirow[t]{2}{*}{ Child support payment } & Yes & 2 & 16.66 \\
\hline & No & 10 & 75.00 \\
\hline \multirow[t]{4}{*}{ Housing arrangement } & Own house & 3 & 25.00 \\
\hline & Family house & 4 & 33.33 \\
\hline & Rental house & 2 & 16.66 \\
\hline & $\begin{array}{c}\text { Housing for the Poor project } \\
\text { house (PPRT) }\end{array}$ & 3 & 25.00 \\
\hline
\end{tabular}

$(\mathrm{N}=12)$ 
It is important to note that three of the respondents $(25 \%)$ do not have paid income. Further enquiries reveal that the first respondent suffers hearing impairment due to domestic violence. She has 4 children aged between 5 and 14 years old. Her former husband is in prison for drug problem and receives no child support payment. All of them are living with 10 other occupants at her parent's crowded home. The second respondent has health problem caused by skin allergy. She has 4 adult children and 3 school going children. She receives transfers from her adult children to support herself and her young children and again with no child support payment from her former husband. On a brighter note, she owns a house from Housing for the Poor project. The third respondent is not currently working as she has just moved from Kuala Lumpur after the divorce. To make things harder, her only child is asthmatic and has cleft lip. She is looking for a job yet childcare issue has dampened the effort. The respondent and her child are living at her sister's rental home. The results of the study also detail that single mothers who did not work in this study were due to their health problems such as hearing impairment and skin disorders and disabled child care problems.

Most of the respondents (83\%) receive monthly financial assistance from the Welfare Department. Under the Child Welfare Assistance Scheme, single mothers who comply with special eligibility criteria are given a minimum of RM100 per month for one child and a maximum of RM450 per household for those who have more than 4 children. The receiving respondents in this study receive between RM100 and RM400 per month. The amount may seem insignificant for many people however for the poor it represent a considerable percentage of their total monthly income, in particular in the absence of child support payment from their former husband. Here, public welfare assistance can reduce the burden faced by low income single mothers in fulfilling their daily needs [24]. This study also highlights another important point which is the number of children that these Malay single mothers have. The national statistics show that a Malay family has 3 children on average. Our small here shows that 8 of the 12 respondents have more than 3 children with 2 respondents have 7 children each, indicating that there are more mouth to feed with their meager income. Thus poverty creates insufficiency and hardships for every member of the family [1].

Housing arrangement post-divorce is one of the most important issues that come to the mind of single mothers. In this study we find that the respondents have a place to stay though the living conditions some of respondents are uncomfortable as they have to share the space with other extended family members. Some of the respondents have to return to their parents and siblings home as they have not own a home of their own. Also, the federal government and the Kelantan Religious Department effort to provide homes for the poorest of the poor has benefitted many of the respondents as rentals expenses will definitely increase the financial burden of single mother households. Therefore, public assistance plays an important role in improving the capability and potential of human capital - in this case the single mothers and their children [25].

\section{Conclusion}

In a nutshell, this preliminary study presents the story of hardships among selected single mother households in Kelantan. We find that demographic and socio-economic factors play important roles in the wellbeing of the respondents. Low education attainment seems to cause the respondents to have low paying jobs exacerbated by more than average number of children in the households. Poverty and hardships come hand in hand therefore public assistance in the form of cash and kinds have somehow reduced the burden of single mothers in this study who earn below national minimum wage. The findings 
further highlight the additional burden faced by the single mothers in this study and also other single mothers in general - the absence or the irregularities of child support payments from absent fathers. This is not a small issue and warrant comprehensive studies on its own. Currently efforts have been made to improve the child support payments in the country yet the results remains far from the desired level. Law enforcement has to be carried out by multiple agencies upon the noncompliance of child support payments to ensure the welfare of the children and avoid child poverty.

In a quest to achieve a higher standard of living for all the people in the country, special attention has to be given to the vulnerable groups in the society including the single mother households as they sole breadwinner and care giver in the family. They may be raising the children who are the future generation of this country in hardships. They deserve to be assisted with dignity.

\section{References}

1. Kartini, A., T.,"Dilemakemiskinan: Falsafah, budaya dan strategi". Akademika, 2016, $86(2), 65-78$

2. Hamidah, S., Siti, H., H., Norfaezah, M., K., Norsafatul, A., A., R., \& Nurhasbuna, S. "Parental involvement and their relationship to emotional well-being of adolescent in urban poverty areas". International Journal of Religion Research in Education, IJRRE, 2017,1(2),8395

3. Jabatan Perangkaan Malaysia. "Laporan banci penduduk dan perumahantahun" 2010

4. Jabatan Perangkaan Malaysia."Laporan penyiasatan pendapatan isi rumah dan kemudahan asas tahun, 2016

5. Farah, A., A., N. "Zakat and poverty alleviation: Roles of zakat institutions in Malaysia", International Journal of Arts and Commerce, 2012, 1(7), 61-72.

6. Osman, R. "Daerah-daerahkemiskinan", siri kajian ekonomi dewan. Dewan Bahasa dan Pustaka: Kuala Lumpur 1995.

7. Kenny, C. "Why are we worried about income? Nearly everything that matters is converging."World Development. 2005, 33(1), 1-19.

8. Krishna, A., Kapila, M., Porwal, M., \& Singh, V. "Why growth is not enough: Household poverty dynamics in Northeast Gujarat, India", Journal of Development Studies, 2005, 41(7),1163-1192.

9. Siwar, C., Ahmed, F., Bashawir, A., \& Mia, M., S. "Urbanization and urban poverty in Malaysia: Consequences and vulnerability". Journal of Applied Sciences, 2016, 16(4),154160.

10.Siti, M., Z., Nor, B., A., K., \& Khairul, H., B. "Marital status, career and income as indicators of life satisfaction among middle-aged career women in Hulu Langat, Selangor, Malaysia".Populasi, 2017, 25(1),1-15.

11.Joshua,D.,Joel,T.,N.,\&Meghan,R.,L."Sex difference in delaying family: Effects on job and life satisfaction",Psychology Research, 2016, 1(6), 444-452.

12.Brady, B., \& Rebekah, B. "Targetting, universalism and single mother poverty: A multi-level analysis across 18 affluent democracies"(LIS Working Paper No. 554). Luxembourg Income Study (LIS):Luxembourg 2010.

13.Sakinah, H., Yusoff, N., A., M., Shariza, A., R., Teoh, C., M., Y, Hayati, M., Y. "Nutritional status and health profile among single mothers in Kota Bharu, Kelantan.", J. Fundam. Appl. Sci. 2018, 10(IS), 453-466

14.Naresh, K., Abdullah, A., M., Mohamed, D., I., \& Mohd, N., H., Y. "Entrepreneurial orientation and antecedents of low-income household heads in Kelantan, Malaysia" ,Journal of International Studies, 2018, 11(1),140-151

15.Siti, M., R., A., R., \&Narimah, S. "Family poverty and its influence on rural community low education: Case study in Bachok District, Kelantan.", Journal of Social Sciences and Humanities, 2018, 13(12),11-23 
16.Zurina, A., S., Hukil, S. \&Norinsan, K., O. "Characteristic of education and socio-economic population at Sungai Budor Village, Kelantan.”, Journal of Social Sciences and Humanities, 2018, 13(3),222-233

17. Ahmad, F., M., A., \&Mohd, F., I. "Determination of poverty among the poor and needy in a developing country”.,Journal of Emerging Economies and Islamic Research, 2018, 6(2), 47 61

18. Blumberg, G., G. " Balancing the interest: The american law institute's treatment of child support”, Family Law Quarterly, 1999, 33,39-110.

19.Bartfeld, J."Child support and post-divorce economic wellbeing of mothers, fathers and children., Demography”, 2000, 37, 203- 213

20.Siti, M., Z., Noremy, M., A., \& Faradillah, I., O. (Eds). "Kesejahteraan psikologi ibu tunggal: Cabaran sebagai ibu tunggal dan tekanan hidup". Dalam Persidangan Antarabangsa Sains Sosial dan Kemanusian, KUIS:Selangor 2018

21. Qurratulain, A., S., \& Mahpara, B., S. "Measuring and modelling women's economic empowerment in Pakistan", Journal of Asia Pacific Studies, 2015, 34, 43-55

22.Nor, D., A., Laily, P., \& Husniyah, A., R. "Masalah kewangan dalam kalangan keluarga berpendapatan rendah di Semenanjung Malaysia.",Jurnal Pengguna Malaysia, 2010, 15,18-31

23. Mohammad, Z., Z., \& Isma, a., J "Perception of aid scheme recipients towards the roles of welfare agency in Malaysia", Journal of Human Capital Development, 2018, 11(1).68-78

24. Siti, R., A., H., \& Sakinah, S. "Exploring single parenting process in Malaysia: Issues and coping strategies", Social and Behavioural Sciences, 2013, 84, 1154-1159

25.Nor, A., A., Siti, D., \& Nurul, N., A., H. "Prestasi pengusaha wanita: Hasil pembentukan faktor modal insan dan dayasaing.", Journal of Social Sciences and Humanities, 2018, 3(3), 173-188

26.Zakiah, J. Kemiskinan "dan keciciran dalam pendidikan”, Jurnal Kebajikan Masyarakat, 2011, 37(6), 5-20 